\section{Passport for Life:}

Teaching using Primary Sources
GI_Forum 2020, Issue 2

Page: 29 - 44

Full Paper

Corresponding Author: yaar.tal@gmail.com

DOI: 10.1553/giscience2020_02_s29

Israel Ben Dor ${ }^{1}$ and Tal Yaar-Waisel'

'Oranim Academic College of Education, Israel

\begin{abstract}
For Tal Yaar-Waisel, finding her great-grandmother's passport was a shocking experience. The 'Deutsches Reich' passport, stamped with the Nazi seal, allowed Karoline Bloch (Dr YaarWaisel's great-grandmother) to leave Vienna just two days before Kristallnacht, 9 November 1938, saving her life and enabling her to join her daughter's family in Nesher, in Mandatory Palestine.

This study intertwines Karoline's story, history, research and experimental pedagogy. The personal story of Karoline Bloch, a Holocaust survivor from Vienna, is discussed against the background of the persecution of Austrian Jews and the destruction of their community. Her passport reflects her personal suffering and salvation, and is discussed in relation to immigration policies at the time. From the research point of view, the study deals with geomedia as working tools that can be used to widen the interdisciplinary dimensions of passports. The authors used the passport as the basis for inquiry-based teaching of the broader historical subject. The combination of a personal story, historical background, and facilitating students to work as geomedia researchers, asking questions and finding answers, generated the students' interest and rendered them capable of thinking about the meaning of the subject for themselves.
\end{abstract}

\title{
Keywords:
}

passport, Austrian Jewry, geomedia, primary sources, inquiry-based teaching, multidisciplinary teaching, immigration

\section{Introduction}

A single document or picture is sometimes an 'historical treasure' through which we can experience a direct encounter with the past, in which a meaningful experience is created that leads to valuable learning. Such 'pearls' are not found only in museums; sometimes they are literally within our reach, just waiting for us to find and recognize them. In 2012, Tal YaarWaisel was sorting out photographs and documents in her parents' home, and came across the passport of her great-grandmother, Karoline Bloch, which was issued in Vienna in 1938. Finding the passport was thrilling. 
The 'Deutsches Reich' passport, stamped with the Nazi seal, allowed Karoline Bloch (Dr YaarWaisel's great-grandmother) to leave Vienna just two days before Kristallnacht, 9 November 1938, saving her life and enabling her to join her daughter's family in Nesher, in Mandatory Palestine. Within nine months, after her husband's death in February 1938, followed by the German annexation of Austria in March, Karoline lost everything she had, and her survival depended on her passport. Miraculously, because her children had left Austria before those tragic events, she could choose between two destinations (Palestine or Brazil) at a time when few people had any choice. The personal story reflects the history and destiny of many millions, Jews and others, who were persecuted and displaced in the $20^{\text {th }}$ century.

After years during which Dr Ben Dor, a senior teacher of history, had taught students about the unification of Germany and Austria and the persecution and expulsion of Austria's Jews, it was possible to see in the passport, clearly and symbolically, the tragic and human power of these events. Austria was united by force with Germany and the passport is therefore one of Nazi Germany, with the words 'The German Reich' emblazoned at the top; under them are the Reich Eagle of Nazi Germany and a swastika. On the left-hand side of the passport, in red ink, is the letter J, showing that the passport's owner was a Jew (Jude). Beside the letter 'J', the date 12.10.1938 appears vertically. (See Figure 1.) The passport was issued on 29 September 1938; from October 1938, Jews had to carry special passports which identified them as Jews. The directive derived from a Swiss initiative, which sought to prevent the arrival of a stream of Jewish refugees (Barkai \& Mandes-Flor, 2005: 212). Karoline received the passport just before the directive came into force; the letter 'J' and the date (12.10.38) were added later. The passport is written in German, but it also includes words in English, Portuguese and French.
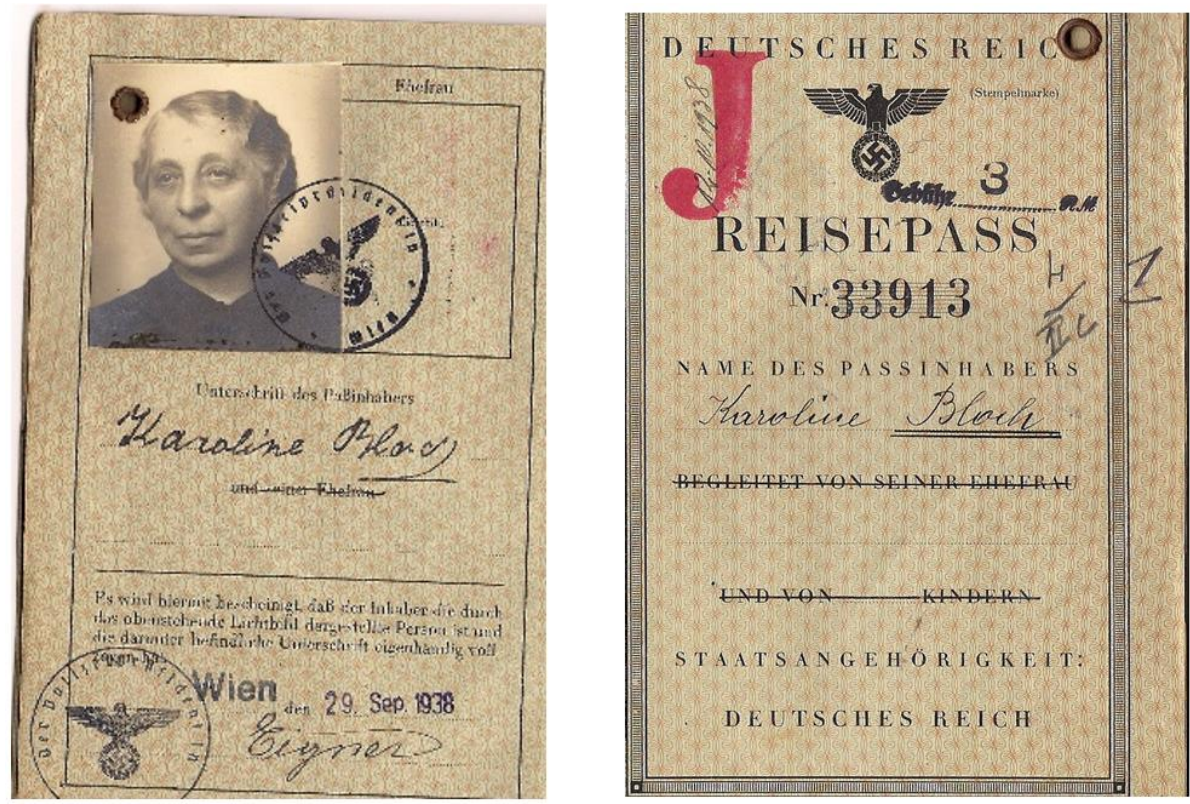

Figure 1: Evidence of the 'Anschluss' in Karolyne's passport 


\section{Passports as historical documents}

The uniqueness of Jews as a separate collective, but one lacking territorial sovereignty while being transnational in nature, stands in contrast to the increased importance of passports in the nation states of Europe after World War I. Between the two world wars, a passport becomes a means of differentiation and exclusion (Keshavarz, 2018). The nation states established after the disintegration of the empires used passports as a device for limiting the freedom of movement of all those who had lost their citizenship and become refugees. For many Jews, holding a passport was one of the first steps to ensuring their survival. But as a nation without a state, Jews suffered. The inability to solve the problem of refugees on the eve of World War II merged with the inability of nation states to deal with the question of Jewish existence. After the Nazi regime came to power, the risks faced by Jews increased, from expulsion to genocide (Jean, 2011).

The renowned Austrian-Jewish, anti-Nazi writer Stephan Zweig (1881-1942), a refugee in Brazil, in his autobiographical book The World of Yesterday (1942), records the tragedy of the German and Austrian Jewish intellectuals who were forced to live as wandering Jews. Zweig and his wife, out of despair at their status as refugees and the catastrophic situation of Jews in Europe, committed suicide immediately after he had finished writing his book. Many other Austrian Jews likewise took their own lives (The National Library of Israel) (Gulddal \& Charlton, 2017).

For Zweig, the introduction of passports after the First World War symbolized an attack on individual liberty. People travelling had to deal with bureaucrats who blocked international borders. Zweig's memoirs document his own trauma when his passport became null and void after the annexation of Austria in 1938 (Zweig, 1964: 408-411).

The internet can serve as a tool in the search for complementary information to personal stories and illustrations of the wider historical context, as can be illustrated with reference to Felix Nussbaum (1904-1944), a German-born Jewish artist who was murdered in Auschwitz. In his paintings, he expressed the despair of Jews as displaced and rejected human beings. In 'The Refugee' (1939), we see a man sitting with his back bent, holding his head in his hands; on a table is a globe, symbolizing how the entire world is closed for the Jews. In another painting, from 1943, 'Self Portrait with a Passport'1, Nussbaum depicts himself holding a passport that bears no visible country name and wearing the yellow Star of David that identified Jews (Yad Vashem, 2020).

The passport not only grants free movement, but also validates the personal history, identity, and connection to place and community of its holder; removing or denying a passport also removes any foundation of personal status (Gulddal \& Charlton, 2017).

A passport is one of the most basic personal documents of the modern era (Keshavarz, 2018), and archives contain numerous examples which tell the personal stories of survivors and victims of the Holocaust. For example, the Yad Vashem Archives in Jerusalem have more than 2,000 passports, and over 4,000 are stored in the US Holocaust Museum in Washington. The ready availability of passports creates an opportunity for instruction in the context of History

\footnotetext{
${ }^{1}$ The interested reader will be able to find reproductions of both works online.
} 
and Geography education in schools. Using the data, stamps and symbols found in a passport, it becomes possible to trace a personal story and its wider connections. On the one hand, the passport itself was always, and remains today, a document designed to help the traveller; but the passport system has become increasingly used to block unwanted immigrants, and to protect the state and its citizens from threats, real or imagined. Therefore, the passport is relevant to several key contemporary debates concerning internal and international relations (Keshavarz, 2018; Torpey, 2000).

\section{Geomedia and passports}

Geomedia enable the visualization of digital information from various geographic and historical sources. The digitization of geographical information of all kinds allows bridges between citizens and efforts to solve global problems by connecting social media participants. Geomedia also create learning opportunities that can empower students and lead to flexible, personalized, learning based on critical thinking. Their use can also promote complex multidisciplinary approaches to issues (Donert, 2014: 9-10; Fast et al., 2018).

Nowadays, when virtually every student has, or has access to, a mobile phone, tablet or computer, geomedia can help students to develop their spatial understanding of the world, for example in Project Based Learning, as demonstrated in this study. Vienna in the 1930s can be studied through maps and photographs, and the historical city can be compared to current satellite and photographic imagery. It is possible to identify the sites where Karoline's life was conducted during the 1930s, and the locations of Jewish community institutions at that time.

The use of geomedia helps students and researchers to decipher the course of life during World War II. Students can research a relative's or another person's passport. For example, the German passport (issued on 9 March 1935) of Alfred David Les, a distant relative of one of the authors of this study, who was born in Schwedt on the Oder River (now located on the German border with Poland), allows us to follow his way to 'Palestina'. Alfred was sixteen at that time. On 19 June, the passport was stamped at the British Consulate in Berlin with a B3 visa for Palestine, a type of visa intended for students who had been admitted to higher education, usually with some scholarship. On 25 June, he crossed the border into Trieste, which was under the control of Italy; the next day he boarded a ship, and on 1 July 1935 his passport was stamped when he arrived in the port of Haifa. The passport saved him from Nazi persecutions, but his family did not survive. Alfred enlisted in the British army in World War II and fought against the German army in Italy with the Jewish Brigade.

As illustrated by the case of Alfred David Les, the internet serves as a tool in the search for complementary information to a personal story.

\section{Persecution of Jews in Austria and destruction of the community}

Persecution of Jews in Germany and the restriction of their movements began immediately after Hitler's rise to power in 1933. The Nuremberg Laws (1935) voided their German citizenship and made them outcasts. In 1938 there was a sharp turn for the worse when on 12 
March German military units annexed Austria to Germany in the 'Anschluss'. At that time, there were around 185,000 Jews in Austria, of whom about 170,00 were in Vienna (Rosenkratz, 1990: 24). Pogroms against the Jews of Vienna had begun even before the entry of German soldiers, with Germany seeking to implement in the city all the methods of the persecution of the Jews in Germany, as carried out from 1933 onwards. However, within a short time their anti-Jewish policy became even more far-reaching and brutal than in the 'Old Reich' (Bata, 2002). Teachers and leaders of the Jewish community in Vienna were sent to Dachau concentration camp. Jewish property was confiscated in the framework of accelerated 'Aryanization'. On 20 August 1938, leading Nazi Adolph Eichmann moved into Vienna and took over other sites in Vienna, acting rapidly, with the enthusiastic help of friends in the Austrian Nazi party, to dispossess and deport the Jews. His staff humiliated, beat and robbed Jews who came to arrange the necessary forms (Barley, 2007: 322-323). During September 1938, when blackout was enforced in preparation for aerial bombings, Jews were thrown under the wheels of tram cars; synagogues in Vienna were attacked on Yom Kippur, and Torah scrolls and religious books were burned in the street.

Before the outbreak of the war, more than two-thirds of Austria's Jewish population (around $128,500)$ had emigrated to 89 countries. The main destinations were Britain $(30,850)$, North America $(28,700)$, China $(18,124)$, Central and South America $(11,580)$ and Palestine $(9,195)$. More than one-third (more than 65,000) died in the ghettos and camps in eastern Europe. At the end of the war, about 1,000 Jews survived in Vienna, one-third of them in hiding. The rest were employed by the Gestapo to sort the tremendous quantities of property confiscated from Jews (Rosenkratz, 1990: 27-28).

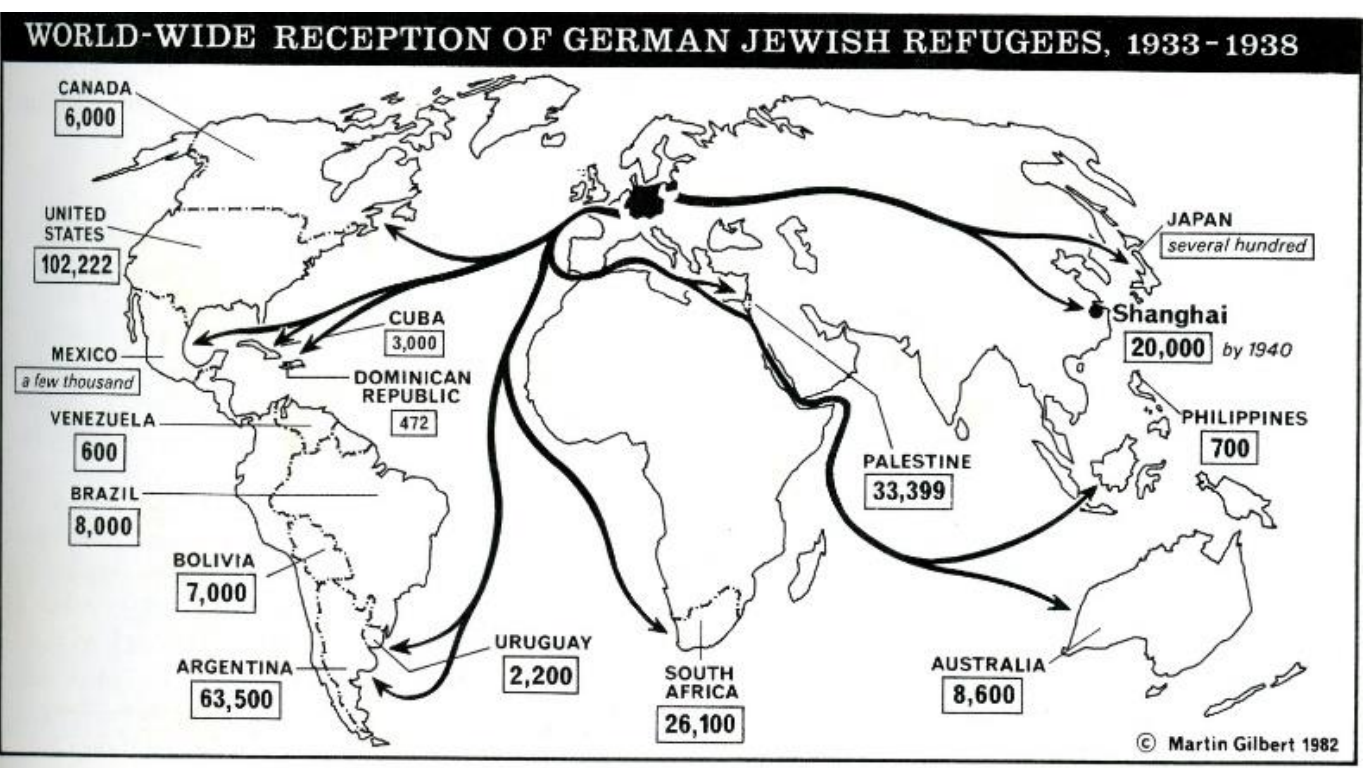

Figure 2: Worldwide diaspora of German (including Austrian) Jewish refugees, 1933-1938 (Gilbert, 1982: 23) 


\section{Immigration Policy in the 1930s and 1940s}

Jewish people in particular were especially vulnerable to immigration policy, which was regulated heavily by using passports as well as other means. The USA was particularly severe in its restrictions on immigration from Germany and Austria, while most of those who applied for a visa were Jews. In 1939, for example, 24,000 applicants received visas while 241,000 (Yad Vashem) remained on the waiting list. Many of them could have been saved by a more generous immigration policy. Karolyn Bloch herself fell foul of this policy: in 1940, when she was already in Palestine, her application for an American visa to join her son was refused by the American consul.

Karolyn was also affected personally by the immigration policies of both the British Mandate in Palestine and Brazil.

From the early 1920s, the British Mandate in Palestine defined seven categories of immigrants, indicated by the letters A to $\mathrm{G}$. The British preferred immigrants who held property and who exercised necessary professions (category A). Between them and the Jewish Agency (the representative organization of the Jewish community in the British Mandate), there was constant disagreement about immigrants from category $\mathrm{C}$ - workers who lacked property according to the British definition and who were 'pioneers' according to the Zionist definition. Karoline's visa was of category D - 'women, children, and others, who depend on the residents of the land' (Shavit \& Biger, 1982: 101). In addition, the Jewish Agency provided Karoline, through its Chamber of Immigration in Vienna, with an immigration certificate. This printed document, in Hebrew, was like the passport of the as-yet non-existent Jewish state and was given to all legal immigrants to the British Mandate.

In the years 1929-1939, about a quarter of a million Jews immigrated to the Land of Israel in the context of the 'Fifth Aliya', or wave of immigration. Jews from central and eastern Europe were prominent, and included Jews from Germany and Austria who were fleeing Nazi persecution. In part, this was illegal immigration, as the British had limited the immigration to the Land of Israel of Jewish refugees from Europe since 1934. Their numbers doubled after Germany's annexation of Austria, which led to the Évian Conference in July 1938, the outcome of which was that not a single country (with the exception of the Dominican Republic) was willing to accept Jews in large numbers. In 1939, the Jewish community in Mandatory Palestine reached 450,000. Gradually, Britain neglected its obligation to the realization of Zionism, and in May 1939 in the Third 'White Book' (British government policy document), it restricted the immigration quota to just 75,000 Jews over five years. Throughout World War II, the British rigidly prevented Jewish immigration to the Land of Israel, and in 1940-1944 immigration was even below what was permitted by the White Book. The gates to the Land of Israel were locked at the very time that the Holocaust occurred in Europe.

As mentioned, one of Caroline's three sons emigrated to Brazil and settled in Sao Paulo. In Brazil, in the 1930s, the elites were hostile to Jews and considered them a Communist threat. As a result, Brazil restricted immigration quotas, and on 7 June 1937 the Brazilian Foreign Ministry secretly forbade representatives of Brazil in Europe to grant entry visas to Jews (BenDror, 2002). Following this directive, the number of Jews who immigrated to Brazil declined 
by $75 \%$, although some officials ignored the explicit instructions they received. The Brazilian ambassador to France, for example, continued to grant visas during 1940-1941.

Such diplomats, who were recognized later by Yad Vashem as 'Righteous Among the Nations', acted courageously, succeeding in saving thousands of Jews. Other prominent examples include Sempo Sugihara, the general consul of Japan in Kovno, Lithuania, who issued 3,500 Japanese transit visas to Jewish refugees in the summer of 1940, and Raoul Wallenberg, a Swedish diplomat in Budapest, who provided thousands of Jews with Swedish passports (Righteous Among the Nations - Yad Vashem Website).

\section{Karoline Bloch's life was saved}

Karoline Bloch was born in 1877. When she was 19 years old, in 1896, she married Moritz (Moshe), and the couple had three sons, Heinrich, Rudolph and Alfred, and a daughter, Gertrude. Two of the boys served in the Austrian army in World War I.

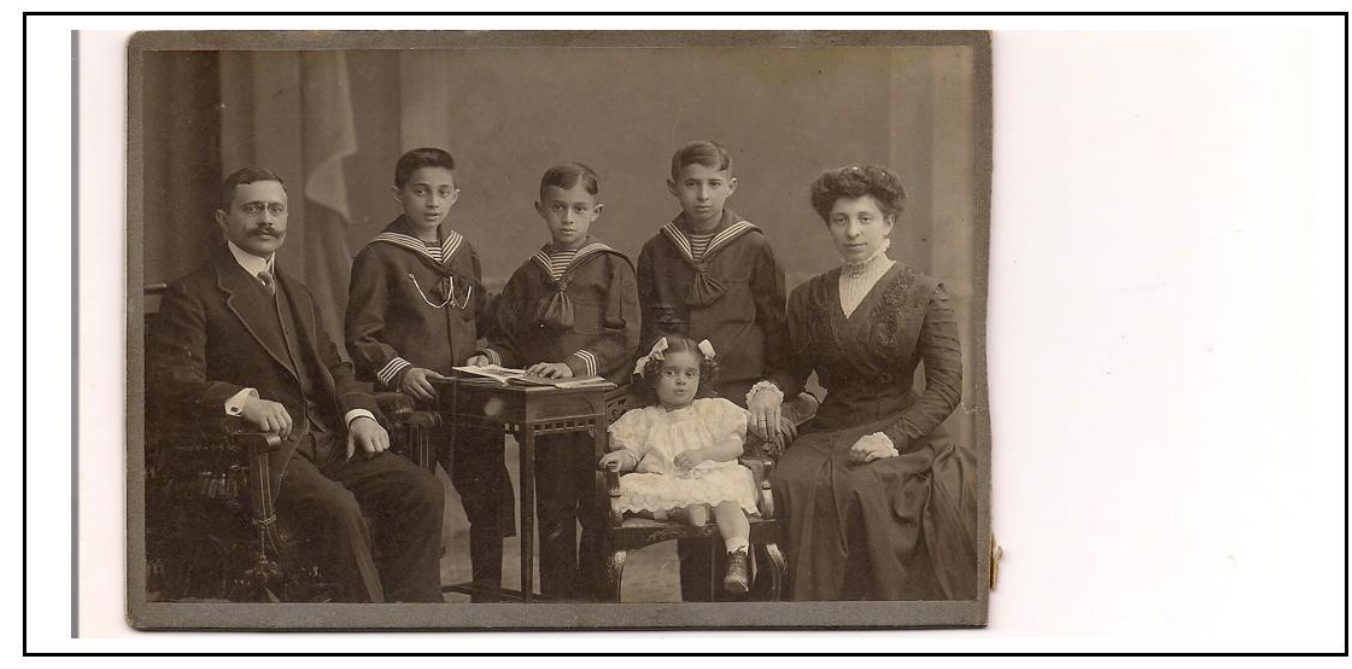

Figure 3: The Bloch family, Vienna, 1909

At the start of the 1930s, the boys emigrated from Austria: Heinrich to the United States, Rudolph to Sao Paolo, Brazil, and Alfred to England. In 1934, a year after Adolph Hitler came to power in Germany, their daughter Gertrude and her husband, Dr Rudolph Steinhertz, reached the conclusion that there was no future for Jews in Europe, and they immigrated to the Land of Israel, along with their daughter, the infant Zuzanna. They settled in Nesher, a working-class neighbourhood in the south of Haifa, beside the Nesher Cement Factory. Rudolph, a chemist by profession, established the laboratory at the factory, which was the main source of livelihood of the area's residents.

The parents, Moritz and Karoline Bloch, stayed in Vienna. On 13 February 1938, when he was about 70, Moritz died, and Karoline, who was then aged 61, remained alone. 


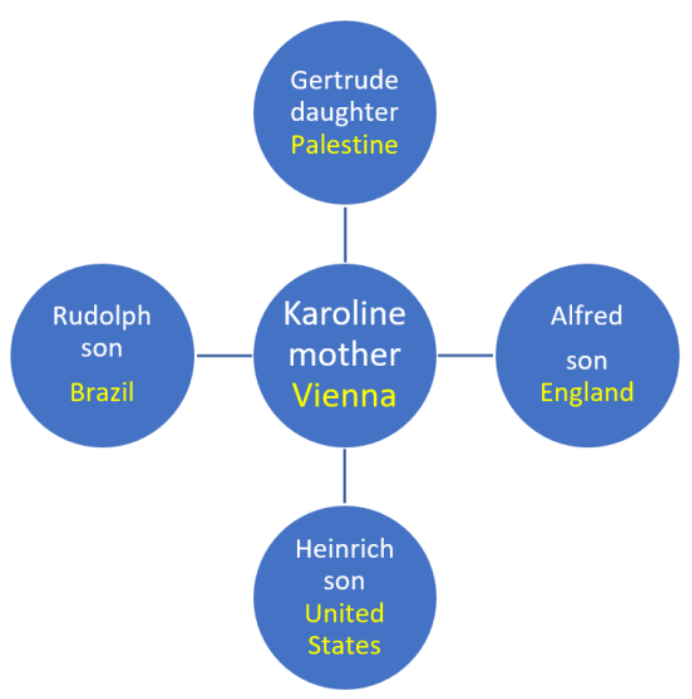

Figure 4: The dispersal of the Bloch family, March 1938

After the 'Anschluss' (just a month later), Karoline's children asked her to make haste and leave Vienna. Thanks to them, she had two good (and rare) options for that time: her son, who had emigrated to Brazil, obtained a visa for her to go to Brazil; her daughter, who had emigrated to the British Mandate in Palestine, obtained a certificate enabling Karoline to immigrate to the Land of Israel. One of the pages of Karoline's passport states in Portuguese that her son is legally in Brazil. On October 27, she was thus able to obtain a visa for Brazil, signed by the deputy consul of Brazil in Vienna. On another page there is a visa for Palestine, issued by the British passport office in Vienna on 15 October. This visa allowed a single journey only and was valid until 30 November 1938. The visa's recipient, it was written, was entitled to remain permanently in the land with the status of immigrant. The visa which enabled Karoline to immigrate to the Land of Israel was issued about five months before the third 'White Book'; the visa for Brazil was even rarer because of Brazil's objection to the immigration of Jews, as outlined above.

On 27 September 1938, the Immigration Division in Haifa informed Rudolph Steinhertz, Karoline's son-in-law, that Karoline had received a type-D certificate - that is, approval for immigration to Palestine following Steinhertz's request of 16 August 1938. In addition to the certificate, the immigrant was required to bring a passport and any other document proving their identity and suitability for immigration. On arriving in Palestine, the immigrant was supposed to give the document to the immigration authorities at the port or border crossing. Karoline was also asked to provide a medical certificate stating that she did not suffer from any serious mental or physical illnesses. Accordingly, on 13 October she went to a licensed physician and obtained the certificate. 


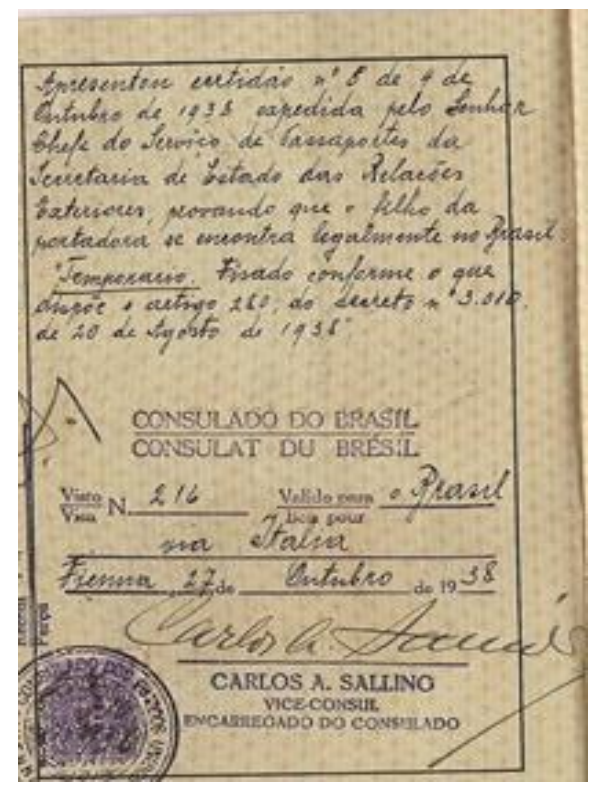

Figure 5: The Brazilian visa

On 7 November, Karoline left Vienna by train for the Italian port of Trieste, where she waited for a ship. Two days later, on the night of 9-10 of November, Kristallnacht occurred. On November 18 she boarded the Marco Polo, a passenger ship of the Italian shipping company Adriatica (Haaretz, 25 November 1938); on 24 November she reached the Port of Haifa, from where she went to her daughter's family in Nesher. Page 9 of her passport illustrates with simplicity the miracle that Karoline Bloch experienced: on the upper part of the page is the symbol of Germany with a swastika and the date she left Vienna (7 November), and under it is the seal of the Immigration Division of the Palestine government, stamped at the Port of Haifa by the inspector of immigration, with the words, in English: 'permitted to remain permanently in Palestine as an immigrant'.

Archival materials for the Adriatica shipping company, including photographs, can be found at: https://adriatica.altervista.org/?id=1\&lang=it.

It could have been hoped that Karoline Bloch's arrival in Palestine would end her hardships, but while she joined her daughter, son-in-law and granddaughter, she never again saw her three sons. These were the days of World War II, the financial situation in the Land of Israel was difficult; bombings by Italian planes and fears of a German occupation marked the years 19401942. Gradually, news of the large-scale murders of the Jews in Europe became partly known and people in Palestine were deeply worried. 


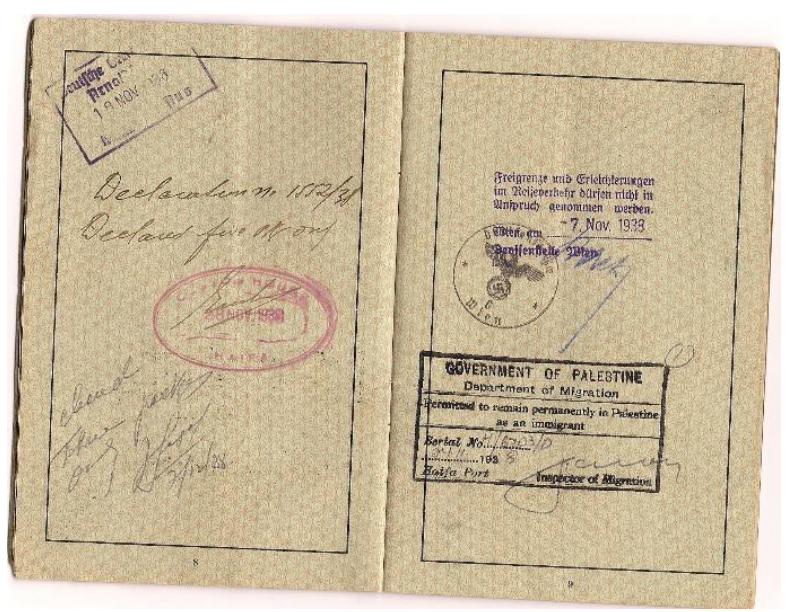

Figure 6: The passage from Nazi Germany to Palestine

Karoline's personal economic situation was difficult. On 2 April 1940, the Mukhtar (the local representative of Nesher-Yagur, a sub-district of the Haifa District) produced a certificate stating that Mrs Karoline Bloch, who had been living in the community of Nesher since 24 November 1938, was a widow with no income, who therefore needed regular financial assistance from her son, Rudolph Bloch, in Sao Paolo, Brazil. In 1940, Karoline attempted to obtain a visa to the United States, which had not yet entered the war, where her son Heinrich lived with his family. On 3 May 1940, the American consul in Jerusalem informed Karoline that her request had been rejected and would not be discussed again in the coming years.

Karoline Bloch died in 1943 and was buried in Haifa. Her daughter and granddaughter often noted that 'it was good that she died without knowing the true scope of the disaster suffered by the Jewry of Europe'.

\section{The interdisciplinary dimension of passport research}

A passport can be a tool for interdisciplinary study. It connects to wider aspects of knowledge: geopolitics, cultural geography, historical geography and geomedia.

In terms of geopolitics, a passport reflects borders as central in shaping foreign policy and immigration. For example, Karoline Bloch's passport reflects Austria's becoming part of Nazi Germany in 1938. In terms of cultural geography, much can be learned about the Nazi regime and the persecution of Jews in Austria from the symbols and stamps in the passport. In terms of historical geography, researchers and students can explore the ways in which overland or marine routes functioned. Further, Karoline's passport reflects the influence of dominant ideologies in the 1930s in shaping state boundaries, and the possibilities for movement and emigration of different ethnic groups.

A passport can serve as a starting point for research. We can look online, for example for the historical sites and buildings that remain today from when Karoline made her journey from 
Vienna, through the port of Trieste, to Haifa, and from there to the working-class Nesher neighbourhood in Mandatory Palestine.

A breakthrough in the research of the geographical history of Vienna was achieved lately with the new website Memento Vienna. This is an online tool that connects archival documents and photographs of victims of the Nazi regime in Vienna to specific locations in the city. Among other things, the app enables the user to explore the last known addresses of those murdered. The process of exclusion, deportation and murder of Austrian Jews becomes retraceable and visible in the city's streets themselves (https://www.memento.wien).

Interpreting the passport is aided by documents preserved by Karoline's descendants, and these too can be expanded by further archival research. Increasing digitization of archives will facilitate such research. Here, we examine connections between the micro-history (Nora, 1989; Ginzburg, 2005) of Mrs Bloch and her family and the wider historical context of 1930s Europe and Palestine. In addition, using passports as primary historical sources allows for the integration of history, geography, art, literature, economics, international relations, international law, political science, genealogy, transportation, communication, sociology and anthropology.

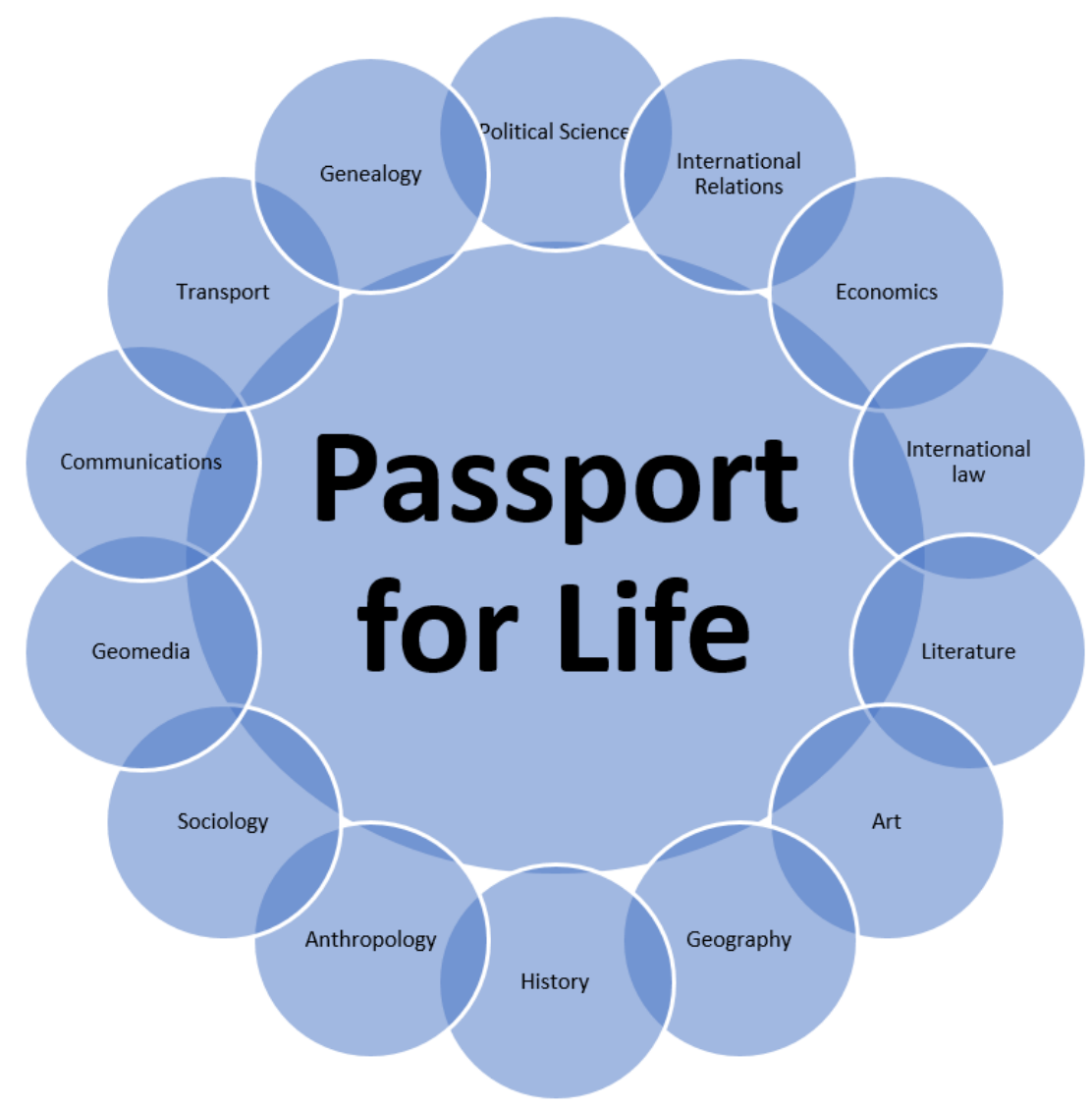

Figure 7: The interdisciplinary dimension of passport research 


\section{Using a Document as a Primary Source in Teaching}

A passport, as a document to be used in specific circumstances, is a primary source: the symbols and the texts in it indicate political organizations, and reflect specific policies and how they were implemented by state officials. Such symbols and texts can also give indications of the bearer's fate.

Through research based on a primary document, unlike the study of history through textbooks, the student acts as a historian, draws conclusions and comes to understand history (Kobrin, 1996). Working with primary sources enables students to construct their own understandings of the past. The process involves them making links between a source and things they already know, making their prior knowledge and the primary source relevant to them. After the research, students provide feedback and describe the significance of their learning.

In recent years in History and Geography education, there has been a broad move to the identification, examination and critical evaluation of primary sources as a central part of the curricula. In Britain, for example, students are required to know how primary sources can reveal knowledge of the past, and they learn how to classify, interpret and evaluate sources in a critical manner. In France, the student is supposed to attain mastery in the reading of different types of source material, to learn how to differentiate between primary and secondary sources, and to identify historical information in sources of all types (Wolf, 2008). This move to the use of primary sources is reflected in the 'Teaching with Primary Sources Partner Program' at the Library of Congress in Washington, which encourages teachers to develop approaches that exploit the primary sources available in the library (https://www.loc.gov/programs/teachers/about-this-program/teaching-with-primarysources-partner-program/).

In the Internet era, the potential has been created to produce added value for primary sources, through the collection of knowledge from other sources and establishing relationships between people and/or resources. Historical research has been strengthened through the addition of testimonies, which until recently were unknown (Orbach-Natanson, 2007).

\section{Inquiry-based teaching: a case study}

The model for Inquiry-based teaching developed and published by Woyshner (Woyshner, 2010) comprises six stages: connect, wonder, investigate, construct, express, and reflect/feedback (and back to connect). The author describes activities for each of the stages.

We used this particular model to teach this chapter of history. The first goal is for students to understand through the passport the complexity of the process of emigration for Austrian Jews on the eve of World War II and to reach their own conclusions about the long-term implications of this process. The student who is examining the historical document, in this case Karoline Bloch's passport, must ask questions, research the family's history, formulate hypotheses about the family's history, and others about the choices they made. After reflecting on their own inquiry work, the students then formulate new questions and search for deeper understanding of the specific historical context. 


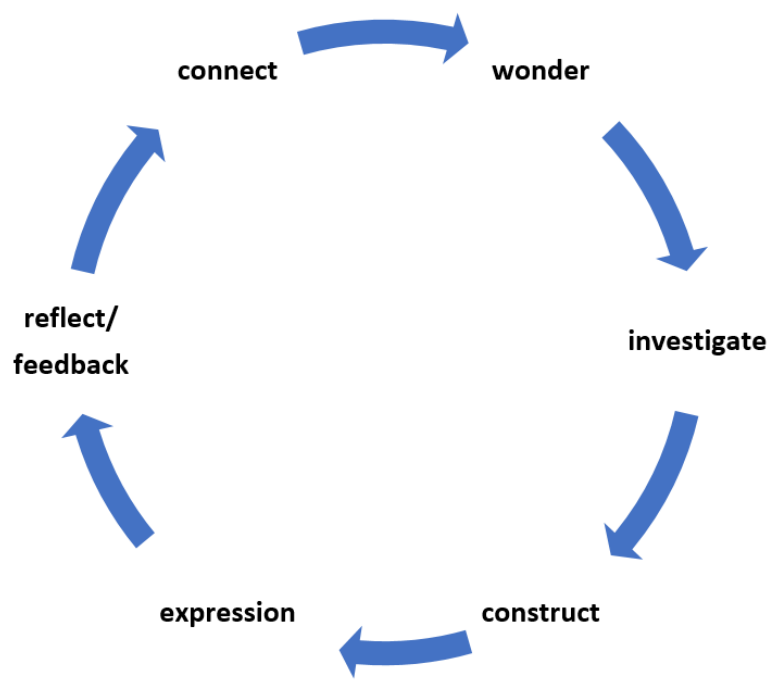

Figure 8: Model for Inquiry-based teaching (simplified from Woyshner, 2010)

Our project was undertaken with student teachers at Oranim Academic College of Education, in the context of one particular course that teaches Project-Based Learning. The project required clarification of basic concepts that were unfamiliar to some students, because of their young ages, and technological changes. For example, postcards, which were widely used by soldiers at the front during World War I, are almost out of use today, in the age of social media.

The story-based approach, which was accompanied by pictures of the actual boxes in which the photographs and passport were discovered, and the findings themselves caused excitement and curiosity. For example, the marking of the letter ' $\mathrm{J}$ ' in red ink on the passport sparked great interest.

The entwining of the personal story with historical events gave rise to questions and requests for clarifications: the rise of Nazism to power in Germany; the annexation of Austria to the German Reich; the 'Anschluss'; 'Kristallnacht'; the British Mandate; illegal immigration to Palestine. Students asked in particular for clarification of 'Palestine - Land of Israel', which was not familiar to them.

Personal photographs showing the everyday life of the Bloch family before the war allowed students to identify with the Blochs, such that they wanted to know what happened to the members of the family. The frequent transitions between the personal story and the historical story succeeded in motivating students to learn about historical processes.

The students cooperated actively in the investigation stage. They were asked to ask questions; on average, they wrote about four questions each. Most of these addressed the particular chapter in history; a third concerned the personal story. The questions show how the lesson prompted students to think 'beyond' the story, for instance: 'My grandmother immigrated to Israel from Poland, my grandfather from Romania, another grandmother from Egypt - what did they experience?'; 'Is the number of immigrants from Europe to Israel during the Second World War identical to the number of immigrants today?'; 'Why do we (and the Ministry of 
Education) teach about the destruction of the community and not emphasize the glory of these communities in Europe?'; 'Does the story of an individual teach about the whole? Is it exceptional?'. Additional questions addressed the Israeli reality after World War II, for instance 'Many Palestinian Arabs underwent the same process as Mrs Bloch did. What is your opinion on the topic? As somebody who experienced similar difficulties and transitions, how would she have addressed them? How would she have behaved?'.

At the 'insights' stage, the students said some very interesting things. 'This was a story lesson - there was a personal story in which there was historical knowledge. You get into the story. This is an experiment because of the integration between knowledge and the personal. A discussion develops: this is the transfer of knowledge from a primary source.'; 'We did not learn only history. We learned some geography, and there were all sorts of topics that were learned through history. In my opinion, this was not a lesson in history.'

The use of primary documents such as certificates and photographs led the students to learn voluntarily and to draw conclusions. For the students, who were largely unfamiliar with the particular chapter of history related to the passport, it was important to understand the processes that accompanied the personal story. Lessons of this type spark curiosity and motivate the student for inquiry-based learning, whether into the history of his/her family or something else. Because of the personal character of the document and the person's individual fate, the learning inspires identification and the ability to understand human distress.

Such a lesson has added value also for the teacher, creating a feeling of mission and responsibility, the desire to stimulate interest, and to combine the personal story with a universal one. This type of teaching enables teachers to create meaningful dialogue with students and to renew their passion for teaching.

\section{Epilogue}

Karoline Bloch's passport illustrates, more than anything else, the destruction of Austrian Jewry under the Nazi regime. However, the passport also provides a wonderful illustration of the fate of one individual and enables us, by using its historical contexts, to see how Karoline succeeded, at the last moment, in leaving Austria, two days before Kristallnacht.

Karoline's descendants kept the passports and other documents, making it possible for future generations to confront painful questions raised by the past. It should be noted that the documentation of this era in history, including the gathering of documents and testimonies, started while the tragic events themselves were still taking place. After the war, wherever Jewish community life emerged, survivors initiated documentation of and research into the Holocaust on a grand scale (Cohen ,2003). The efforts were private ones, carried out by survivors and organized according to cities, areas or countries. Historical commissions were also established. One of the main motives of the survivor-historians was to confront the moral dilemmas that the Holocaust raised. This motive has practical and educational implications. The challenge is to renew faith in the ability of the individual and of society to act in a moral fashion. Research into the Holocaust is thus a matter not simply of the past but also of the present and the future (Cohen, 2003). This is the approach we adopted in educational activities to connect the family 
history with wider history and geography, using the passport as a trigger to generate discussion of moral dilemmas with past and present connections.

In this study, we used the digital databases of the Ghetto Fighters' House Archive and enriched the archive with our own findings. Passport research was made possible by examining World War II passports that can be found on the Web. Teaching methods that guide students to independent research, asking questions and finding answers to them, rely on the resources of the Internet. Above all, we found that students are happy to explore historical issues independently and enjoy using digital tools to do so.

\section{Acknowledgement}

We are grateful to the Ghetto Fighters' House Archive for allowing us to use various family documents and for providing translations of them. https://www.gfh.org.il/eng

\section{References}

Barkai, A., \& Mandes-Flor, P. (2005). The History of the Jews of Germany in the New Era, Jerusalem; Zalman Shazar Center for the History of Israel. (in Hebrew)

Barley, M. (2007). The Third Reich: A New History. Or Yehuda: Zmora Beitan/Yavneh. (in Hebrew)

Bata, M. (2002). The Re-Establishment of a Jewish Community as the Archetype of the Judenrat, in D. Zilberklong (Ed.) Yad VaShem, A Collection of Research Studies, Jerusalem. (pp. 359-370). (in Hebrew)

Ben-Dror, G. (2002), The Catholic Elite in Brazil and the Attitude towards to the Jews, 1933-1939. Yad Vashem Studies, XXX, Jerusalem, 2002, pp. 229-270.

Cohen B. (2003). Bound to Remember - Bound to Remind, in J.D Steinart and I. Weber-Newth (eds). Beyond Camps and Forced Labor: Current International Research on Survivors of Nazi Persecution. Proceedings of the International Conference, London, 29-31 January 2003. pp. 290-300.

Donert, K. (2014). Building Capacity for digital Earth education in Europe. in R.M. Gonzalez (ed.), Innovative Learning Geography in Europe. Cambridge Scholars Publishing. pp. 9-20.

Fast, K. Jansson, A. Lindell, J Bengtsson, L. and Tesfahuney, M. (2018). Geomedia Studies. New York: Routledge.

Gilbert, M. (1982), The Macmillan Atlas of the Holocaust, New York: Scribner.

Ginzbourg, C. (2005), The cheese and the worms. Jerusalem: Carmel. (in Hebrew)

Gulddal, J., Charlton, P. (2017). Passports. On the Political and Cultural Impact of Modern Movement Control. Symploke 25.1-2. pp. 9-23.

Haaretz, 25 November 1938. Historical Jewish Press (JPress) of the NLI \& TAU (in Hebrew).

Harrison, L. (2005). Political Research. Raanana: The Open University. (in Hebrew)

Hecht, D.J., Lappin-Eppel, E., and Raggam-Blesh, M. (2018). Topography der Shoah zweite auflage. Gedachtnidorte des zerstorten judischen Wien. Wien: Mandelbaum.

Jean, Y. (2011). Construction of a Catastrophe: Jews and Travel Documents in Europe between the Two World Wars, In N. Berg (Ed.) Konstellation Uber Geschicbte, Erfahrung und Erkenntnis (pp. 231249). Gottingen: Vandenhoeck \& Ruprecht.

Keshavarz, M. (2018). The design politics of the Passport- Materiality, Immobility, and Dissent. London: Bloomsbury Visual arts.

Kobrin, D. (1996). Beyond the Textbook: Teaching History Using Documents and Primary Sources. Portsmouth, NH: Heinemann. 
Library of Congress, Teaching with Primary Sources, Washington, DC. http://www.loc.gov.

Mddlemis, N. Adriatica and Tirrenia, The Italian Ferry Companies. Shipping. 13 Feb. 2018. https://www.shippingtandy.com/features/adriatica-and-tirrenia.

The National Library of Israel. Stephan Zweig - 70 years. ttps://web.nli.org.il/sites/nli/english/collections/personalsites/archive_treasures/pages/stefanzweig.aspx.

Nora, P. (1989). Between memory and history: Les Lieux de Memoire. Representations 26, pp. 7-25

Orbach-Natanson, B. (2007). Worth a Billion Words? Library of Congress pictures online. Journal of American History 94(1), pp. 99-111.

Rosenkratz, H. (1990). Austria. The Encyclopedia of the Holocaust, A, Tel Aviv: Yad VaShem / Sifriat HaPoalim, pp. 24-28. (in Hebrew)

Shavit, Y., \& Biger, G. (1982). The British Mandate on the Land of Israel: Government, Administration, and Legislation. In Y. Porat \& Y. Shavit (Eds.) The History of the Land of Israel, the Mandate, and the National Home (1917-1947) (pp. 86-105). Jerusalem: Keter/Yad Yizchak Ben-Tzvi. (in Hebrew)

Torpey, T. (2000). The invention of the Passport: Surveillance, Citizenship and the state. Cambridge University Press.

United States Holocaust Museum .How Many Refugees Came to the United States from 1933-1945? https:/ / exhibitions.ushmm.org/americans-and-the-holocaust/how-many-refugees-came-to-theunited-states-from-1933-1945.

Wolf, Y. (2008). A Review of the Literature in the Field of the Teaching of History. Ministry of Education, The Pedagogical Secretariat, The Department for the Development of Curricula, The Henrietta Szold Institute. (in Hebrew)

Woyshner, C. (2010). Inquiry Teaching with Primary Source Documents: An Iterative Approach. Social Studies Research and Practice, 5(3), 36-45. Retrieved from: http://www.socstrp.org/issues/PDF/5/3/2/pdf.

Yad Vashem (2020), Nussbaum, F. The Fate of a Jewish Artist, Online exhibitions: https://www.yadvashem.org/yv/en/exhibitions/nussbaum/index.asp.

Yad Vashem the world holocaust remembrance center. The Righteous among the Nations. https://www.yadvashem.org/he/righteous.html (Hebrew)

Zweig, S. (1964). The World of Yesterday. Lincoln and London. University of Nebraska Press. 